доктор педагогічних наук, професор,

(Уманський державний педагогічний університет імені Павла Тичини)

\title{
РЕГІОНАЛЬНИЙ ВИМІР СТАНОВЛЕННЯ НАУКОВО-ПЕДАГОГІЧНИХ ШКІЛ В УКРАЇНІ: НА ПРИКЛАДІ УМАНСЬКОГО ДЕРЖАВНОГО ПЕДАГОГІЧНОГО УНІВЕРСИТЕТУ ІМЕНІ ПАВЛА ТИЧИНИ
}

Стаття присвячена теоретичному дослідженні становлення та розвитку науково-педагогічних шкіл 6

Украӥні на регіональному рівні. Закцентовано увагу на тому, щзо нині посилюється науковий інтерес до вітчизняних і зарубіжних науково-педагогічних шкіл, які виступають потужним потенціалом 8 підготовці науково-педагогічних кадрів та освітньо-виховному прочесі. Здійснено аналіз основних напрямів діяльності науково-педагогічних шкіл, які функиіонують в Уманському державному педагогічному університеті імені Павла Тичини, виявлено основні тенденції їх становлення та розвитку.

Ключові слова: науково-педагогічні школи, університет, напрями діяльності наукових шкіл.

Постановка проблеми у загальному вигляді та іï зв'язок із важливими науковими та практичними завданнями. Становлення науково-педагогічних шкіл в Україні як феномен розвитку науки і вирощування науково-педагогічних кадрів $\epsilon$ актуальним напрямом наукових досліджень. Адже, найважливішою умовою розвитку будь-якої науки, в тому числі і педагогічної $\epsilon$, за висловом С. Гончаренка, "сувора наступність ідей, концепцій, методів дослідження, які складають зміст науки. Люди різних поколінь, здійснюючи процес наукового розвитку, ніби передають із рук в руки нагромаджений ними "духовний капітал" [1: 7]. Про посилення наукового інтересу до вітчизняних та зарубіжних науково-педагогічних шкіл, які виступають потужним науковим потенціалом та "впливають на освітньо-виховні процеси і підготовку педагогічних кадрів" вказують О. Дубасенюк і О. Антонова [2: 6]. Ми суголосні з їхньою думкою про те, що: "Становлення та розвиток наукових шкіл у кожній країні - це винятково важлива проблема загальнодержавного значення. Від іiі підтримки і послідовного розв'язання значною мірою залежить розвиток тієї чи іншої галузі наукового знання, а відповідно освіти, культури та різних галузей економіки" [2: 6]. Тобто піднята проблема є актуальною і має безперечне теоретичне і практичне значення не тільки на всеукраїнському, але й регіональному рівнях, яке полягає у формуванні наукового потенціалу в закладах вищої освіти та сприяє розвитку педагогічної науки.

При написанні статті нами висувалися завдання: закцентувати увагу на змістовому наповненні поняття "науково-педагогічна школа" запропонованому вітчизняними вченими; визначити тенденції та етапи становлення і розвитку науково-педагогічних шкіл в Уманському державному педагогічному університеті імені Павла Тичини та висвітлити їх основні напрями діяльності.

Аналіз основних досліджень і публікацій із зазначеної проблеми. Питань розвитку наукових шкіл, як педагогічного феномену торкалися О. Адаменко, А. Алексюк, О. Антонова, А. Бойко, В. Вихрущ, Л. Вовк, О. Гнізділова, Н. Дем'яненко, О. Дубасенюк, М. Свтух, С. Золотухіна, Г. Кловак, В. Курило, О. Устенко, О. Сухомлинська, С. Хриков та ін.

Метою статті $€$ довести важливість функціонування науково-педагогічних шкіл в Україні та висвітлити їх напрями діяльності, становлення і розвиток на регіональному рівні.

У процесі дослідження використано загальнонаукові (аналіз, синтез, узагальнення) та педагогічні (конструктивно-генетичний) методи.

Виклад основного матеріалу 3 обгрунтуванням отриманих наукових результатів. 3 метою повнішого висвітлення проблеми регіонального виміру становлення науково-педагогічних шкіл в Україні (на прикладі Уманського державного педагогічного університету імені Павла Тичини) та відповідно до завдань дослідження закцентуємо увагу на змістовому наповненні дефініції "науковопедагогічна школа" запропоноване О. Гнізділовою, яке ми взяли за основу. Під поняттям "науковопедагогічна школа" будемо розуміти "неформальне інтелектуальне об'єднання декількох поколінь педагогів-науковців, що характеризується суттєвими тематично спільними науковими доробками як лідера, так і членів наукової школи, які є викладачами вищих педагогічних навчальних закладів i здійснюють науково-предметну підготовку спеціалістів і кадрів вищої кваліфікації за програмами вузівської і післявузівської професійної освіти, активно впроваджують результати власних фундаментальних і прикладних досліджень у навчально-виховний процес і в педагогічну практику" [3: 80]. Автором виокремлено й основні функції науково-педагогічних шкіл, такі як: освітня, дослідницька, виховна, комунікативна, аксіологічна та функція відтворення [3: 81].

Погоджуємося з думкою С. Гончаренко про те, що, коли наукову школу розглядають як "соціальний 
організм, елементарна структура якого представлена у відношенні "учитель і учні", то це відношення може набувати різного вигляду. Наукова школа може функціонувати в процесі наукового пізнання як соціальний механізм лише тоді, коли, з одного боку, вчений або група вчених націлені на досягнення прогресу знання і передають безпосередньо свої знання великому числу учнів за допомогою друкованих або усних форм комунікації, і з другого боку, коли учні засвоюють цю концепцію і розвивають іiі далі в різних напрямках" [1: 10].

Вчений наголошує й на тому, що "наукові школи не можуть бути запрограмованими ззовні, створеними адміністративним шляхом. Тому ні зовнішнім інстанціям, ані самому керівнику не слід визначати заздалегідь конкретний шлях розв'язання співробітником проблеми дослідження" [1: 10]. Водночас він зазначає, що дещо проблематичним є трактування дефініції "науково-педагогічна школа", тому що воно залежить від розуміння того чим є педагогічна діяльність. У випадку коли ми розглядаємо педагогічну діяльність як систему вищої освіти, тоді мова може йти лише про "співтовариства, які функціонують у рамках освітніх установ, поширивши це поняття на процес підготовки спеціалістів вищої кваліфікації в рамках аспірантури і докторантури або науково-дослідних організацій, які ведуть відповідну роботу" [1:22].

А у випадку коли педагогіка розглядається як "процес передачі знань взагалі, тоді можна вести мову про науково-педагогічні школи стосовно до всіх вищих навчальних закладів і наукових установ. Здається, що найбільш доцільно було б використання поняття науково-педагогічної школи лише стосовно до наукових співтовариств вищих навчальних закладів, оскільки саме педагогічна діяльність $€$ невід'ємною частиною виконуваної ними соціальної функції [1: 22]. 3 цієї позиції і висвітлимо становлення науково-педагогічних шкіл та напрями їхньої діяльності в Уманському державному педагогічному університеті імені Павла Тичини.

Уманський державний педагогічний університет імені Павла Тичини має давню традицію підготовки педагогічних кадрів, починаючи 31930 року. У 2020 році колектив університету буде святкувати 90річчя від дня його заснування. Із колишнього інституту у складі трьох факультетів заклад вищої освіти виріс до університету. Відповідно статус університету вимагав нових підходів до підготовки майбутніх педагогічних працівників та науково-педагогічних кадрів. Це спонукало до створення нових структурних підрозділів - аспірантури, докторантури, спеціалізованих учених рад із захисту дисертаційних досліджень, заснування науково-педагогічних шкіл. Становлення та розвиток науково-педагогічних шкіл в університеті подамо в хронологічній послідовності їх виникнення.

Офіційно перша науково-педагогічна школа "Педагогіка XXI століття" була започаткована у 1993 році, тодішнім ректором університету, дійсним членом НАПН України, академіком Академії наук вищої школи України, заслуженим діячем науки і техніки України, академіком Академії педагогічних i соціальних наук, завідувачем кафедри дошкільної педагогіки та психології, доктором педагогічних наук, професором Володимиром Григоровичем Кузем.

Основними напрямами діяльності його наукової школи є дослідження проблем теорії та історії педагогіки, таких як: організація та функціонування навчально-виховних комплексів "школа-дошкільний навчальний заклад"; вивчення та запровадження ідей педагогічної спадщини В. Сухомлинського в практику сучасної школи; розвиток української педагогічної думки у XX-XXI столітті; розвиток національних цінностей у виховному процесі загальноосвітньої школи; компаративістика як методологічне підгрунтя наукових досліджень; розробка психолого-педагогічних умов соціалізації дітей та молоді; виховання громадянських якостей у школярів та молоді; підготовка майбутніх учителів та вихователів до професійної діяльності [4].

Діяльність науково-педагогічної школи "Проблеми українознавства в освітньому просторі України" (керівник Сивачук Наталія Петрівна - кандидат педагогічних наук, професор, завідувач кафедри української літератури, українознавства та методик їх навчання) розпочата у 1999 році. До іiі складу входять співробітники науково-дослідної лабораторії "Етнологія Черкаського краю".

Напрямами досліджень наукової школи є проблеми: підготовки студентів-філологів до народознавчої роботи в школі; проблеми підготовки студентів-філологів до українознавчої роботи в школі; підготовки студентів-філологів до родинного виховання на засадах народної педагогіки українців; національного виховання в елітарних українських родинах II половини XIX - початку XX століття; формування патріотизму молодших школярів засобами українського фольклору (II половина XIX - перша чверть XX ст.); збереження фольклорної пам'яті регіону; родинних цінностей, родинного виховання в етнопедагогічній традиції історичної Уманщини; підготовки студентів до пошуково-експедиційної роботи з українознавства; підготовки студентів до організації дозвіллєвої діяльності школярів сільської школи на засадах українознавства; виховання естетичних смаків майбутніх філологів засобами народного декоративно-прикладного мистецтва у процесі позааудиторної роботи; методики викладання українознавства в школі; методики викладання фольклору в школі; дослідження народної культури історичної Уманщини вченими XIX-XX ст. (I. Прісовський, Хр. Ящуржинський, В. Ящуржинський, В. Доманицький, О. Діденко, М. Мицик, В. Ілляшевич, П. Чубинський, М. Брижко) [4]. 
Діяльність науково-педагогічної школи "Теорія, історія і практика застосування проектної технології у середній та вищій школі" (керівник - Коберник Олександр Миколайович, доктор педагогічних наук, професор, завідувач кафедри педагогіки та освітнього менеджменту) розпочата у 2000 році, коли О. М. Коберником була захищена перша в Україні докторська дисертація з теорії і методики виховання на тему "Психолого-педагогічне проектування виховного процесу в сільській загальноосвітній школі", в якій автор обгрунтував інноваційну технологію проектування виховного процесу в загальноосвітній школі, за якою працює значна кількість освітніх закладів України. До причин, що визначають актуальність досліджень наукової школи, слід віднести загальну соціальну ситуацію, що негативно впливає на процес навчання і виховання молоді, появу якісно нових вимог з боку суспільства до особистості, розмитість і девальвацію системи традиційних цінностей.

Науковими напрями досліджень науково-педагогічної школи виступають: теоретико-методичні засади проектування виховної системи, виховного процесу та виховної ситуації; теорія і практика навчального проектування; методика організації проектно-технологічної діяльності учнів та студентів [4].

У 2001 році була заснована науково-педагогічна школа "Актуальні проблеми дидактики фізики i астрономії в загальноосвітній школі та фахової підготовки майбутніх вчителів у вищих навчальних закладах" під керівництвом доктора педагогічних наук, професора, завідувача кафедри фізики і астрономії та методики їх викладання, дійсного члена (академіка) НАПН України Мартинюка Михайла Тадейовича. Актуальність проблематики наукової школи полягає в тому, що в умовах оновлення змісту загальної середньої освіти, головним завданням $\epsilon$ необхідність теоретичного і методичного обгрунтування шляхів, методів і технологій модернізації змісту загальної середньої фізичної освіти.

Науковими напрямами досліджень є: модернізація змісту загальної середньої фізичної освіти засобами навчальних програм для учнів загальноосвітніх навчальних закладів; навчально-методичне забезпечення впровадження нового змісту шкільної фізичної освіти; науково-методичні основи впровадження новітніх (у тому числі інформаційно-комунікаційних) технологій навчання фізики i астрономії; розроблення нової методичної системи навчання астрономії в школі та педвузі на базі планетарію як мультимедійної навчальної системи; науково-методичне забезпечення реалізації цілей загальної природничої освіти засобами навчання фізики і астрономії на інтегративній основі; теорія i методика організації продуктивної навчально-пізнавальної діяльності учнів у процесі вивчення фізики [4].

Науково-педагогічна школа "Актуальні проблеми освіти і виховання: історія, сучасність, перспективи" (Керівник наукової школи - доктор педагогічних наук, професор, професор кафедри соціальної педагогіки та соціальної роботи, дійсний член Академії міжнародного співробітництва 3 креативної педагогіки "Полісся" Кочубей Тетяна Дмитрівна) започаткувала свою діяльність у 2005 році на базі наукової лабораторії "В. О. Сухомлинський і школа ХХІ ст.".

Науковими напрямами досліджень $є$ : теоретичні та методичні засади національної освіти і виховання в зарубіжних країнах (Свропа, Канада, Америка); дитинство як суб’єкт і об'єкт педагогічних досліджень; соціалізація і теоретико-педагогічні аспекти соціальної роботи; формування духовно-моральної сфери особистості як теоретико-методологічна проблема; формування здорового способу життя особистості та здоров'язбережувальної компетентності у майбутніх педагогів; розвиток освіти і педагогічної думки в різні історичні періоди, персоналія в історико-педагогічному дискурсі; підготовка майбутніх фахівців у системі багаторівневої педагогічної освіти в Україні та за рубежем [4].

Наукова школа "Екологія, охорона навколишнього середовища: освіта, наука, практика" (Керівник доктор педагогічних наук, професор, завідувач кафедри хімії, екології та методики їх навчання Совгіра Світлана Василівна) заснована у 2009 році. Функціонує на базі науково-дослідної лабораторії "Екологія і освіта" Уманського державного педагогічного університету імені Павла Тичини, результати діяльності членів наукової школи висвітлюються в щорічному виданні "Наукові записки екологічної лабораторії УДПУ".

Науковими напрямами досліджень школи є: розвиток вітчизняної освіти і педагогічної науки; теорія i практика екологічної освіти і виховання; розвиток та вдосконалення екологічної освіти в навчальних закладах; технологія та організація природоохоронних робіт; екологічні проблеми довкілля та шляхи іх вирішення [4].

Напрямами досліджень науково-педагогічної школи "Актуальні проблеми соціального виховання в теорії та історії педагогіки" (керівник - доктор педагогічних наук, професор, завідувач кафедри соціальної педагогіки та соціальної роботи Коляда Наталія Миколаївна) є: розвиток вітчизняної освіти і педагогічної науки; теорія і практика соціального виховання; проблеми педагогічного краєзнавства: структура, функції, принципи та джерела; регіональний принцип у висвітленні проблем соціального виховання в теорії та історії педагогіки; персоналія як тема соціально-педагогічних та історикопедагогічних досліджень; розвиток педагогічної освіти, підготовки та перепідготовки вчителя в Україні; педагогічно-просвітницька діяльність громадських організацій України; розвиток дитячого руху як 
соціально-педагогічного феномену; зарубіжна педагогіка і освіта: історія і сучасність [4].

Започаткувала свою діяльність науково-педагогічна школа "Підготовка майбутнього вчителя до інноваційної діяльності у сільській початковій школі" (Керівник - Комар Ольга Анатоліївна, доктор педагогічних наук, професор кафедри фахових методик та інноваційних технологій у початковій школі) на базі лабораторії "Проблеми сільської початкової школи".

Науковими напрямами досліджень є: вивчення передового педагогічного досвіду роботи учителів сільських шкіл; формування громадянських цінностей молодших школярів; історичні та сучасні питання роботи сільської школи; підготовка майбутнього вчителя до інноваційної діяльності у сільській початковій школі; проблеми та перспективи застосування учителем інноваційних технологій у навчальний процес сільської початкової школи [4].

Підводячи підсумок зазначимо, що від початку заснування університету до сьогодення він пройшов шлях від суто навчального закладу з підготовки педагогічних кадрів до навчально-наукового закладу в якому функціонують науково-педагогічні школи, здійснюється підготовка наукових кадрів в аспірантурі та докторантурі.

Висновки та перспективи подальшого дослідження проблеми. Отже, у процесі дослідження: 1) виявлено основні тенденції становлення та розвитку науково-педагогічних шкіл в Уманському державному педагогічному університеті імені Павла Тичини, до яких відносимо: посилення уваги держави до функціонування науково-педагогічних шкіл при закладах вищої освіти; зміну статусу УдПУ імені Павла Тичини 3 інституту на університет; необхідність здійснення наукових досліджень в університеті, що спонукало до підготовки висококваліфікованих педагогічних кадрів 3 науковими ступенями і званнями; 2) розвиток науково-педагогічних шкіл в університеті поділясмо на два етапи: І-й етап (1993-2000рр.) - заснування перших науково-педагогічних шкіл; II-й етап (2001-2018рр.) становлення та розвиток науково-педагогічних шкіл.

\section{СПИСОК ВИКОРИСТАНИХ ДЖЕРЕЛ ТА ЛІТЕРАТУРИ}

1. Гончаренко С. Наукові школи в педагогіці [Електронний ресурс] / Семен Гончаренко // Освіта дорослих : теорія, досвід, перспективи. - Режим доступу : https:/core.ac.uk/download/pdf/32310530.pdf.

2. Дубасенюк О. А. Проблеми розвитку науково-педагогічних шкіл / О. А. Дубасенюк, О. С. Антонова // Педагогічна газета. - жовтень 2012. - № 10(218).

3. Гнізділова О. Ідентифікація феномену науково-педагогічна школа / Олена Гнізділова // Педагогічні науки. 2014. - № 60. - С. 76-84.

4. Наукові школи [Електронний ресурс]. - Режим доступу : https:/nauka.udpu.edu.ua/naukovi-pidrozdily/naukovishkoly/.

5. Хриков Є. М. Чинники розвитку науково-педагогічних шкіл в Україні / Є. М. Хриков // Становлення i розвиток науково-педагогічних шкіл: проблеми, досвід, перспективи : [зб. наук. праць] / за ред. В. Кременя, Т. Левовицького. - Житомир : Вид-во ЖДУ імені Івана Франка, 2012. - 692 с.

\section{REFERENCES (TRANSLATED \& TRANSLITERATED)}

1. Goncharenko S. Naukovi shkoly v pedagogitsi [Scientific Schools in Pedagogy] [Elektronnyi resurs] / Semen Goncharenko // Osvita doroslykh : teoriia, dosvid, perspektyvy [Adult Education: Theory, Experience, Perspectives]. - Rezhym dostupu : https://core.ac.uk/download/pdf/32310530.pdf.

2. Dubasenyuk O. A. Problemy rozvytku naukovo-pedagogichnykh shkil [Problems of Development of Scientific and Pedagogical Schools] / O. A. Dubasenyuk, O. Ye. Antonova // Pedagogichna gazeta [Pedagogic Newspaper]. Zhovten' 2012. - № 10 (218).

3. Gnizdilova O. Identifikatsiia fenomenu naukovo-pedagogichna shkola [Identification of the Phenomenon of Scientific and Pedagogical School] / Olena Gnizdilova // Pedagogichni nauky [Pedagogical Sciences]. - 2014. № 60. - S. 76-84.

4. Naukovi shkoly [Scientific Schools] [Elektronnyi resurs]. - Rezhym dostupu : https://nauka.udpu.edu.ua/naukovipidrozdily/naukovi-shkoly/.

5. Khrykov Ye. M. Chynnyky rozvytku naukovo-pedagogichnykh shkil v Ukraini [Factors of Development of Scientific and Pedagogical Schools in Ukraine] / Ye. M. Khrykov // Stanovlennia i rozvy'tok naukovopedagogichnykh shkil : problemy, dosvid, perspektyvy [Formation and Development of Scientific and Pedagogical Schools : Problems, Experience, Perspectives] : [zb. nauk. prats'] / za red. V. Kremenia, T. Levovyts'kogo. Zhytomyr : Vy'd-vo ZhDU imeni Ivana Franka, 2012. - 692 s.

\section{Кочубей Т. Д. Региональное измерение становления научно-педагогических икол в Украине: на примере Уманского государственного педагогического университета имени Павла Тычины.}

Статья посвящена теоретическому исследованию становления и развития научно-педагогических школ в Украине на региональном уровне. Акцентировано внимание на том, что сейчас усиливается научный интерес к отечественным и зарубежным научно-педагогическим иколам, которые выступают мошным потенциалом в подготовке научно-педагогических кадров и образовательно-воспитательном проиессе. 
Осуществлен анализ основных направлений деятельности научно-педагогических школ, функиионирующих в Уманском государственном педагогическом университете имени Павла Тычины, обнаружено основные тенденциии их становленья и развития.

Ключевые слова: научно-педагогические школы, университет, направления деятельности научных школ.

\section{Kochubei T. D. Reginal Dimension of Scientific and Pedagogical Schools Development in Ukraine: Focus on Uman State Pavlo Tychyna Pedagogical University.}

The article is devoted to the theoretical study of the formation and development of scientific and pedagogical schools in Ukraine at the regional level. The emphasis is set on the growing scientific interest in native and foreign scientific and pedagogical schools, which are a powerful potential for the scientific and pedagogical staff training and educational domain. The analysis of the main directions of the scientific and pedagogical schools activity functioning in Uman State Pavlo Tychyna Pedagogical University is carried out, Writing this article, general scientific methods (analysis, synthesis, generalization), pedagogical (constructive and genetic) were used.

In the course of the research: 1) the main tendencies of the formation and development of scientific and pedagogical schools in the Uman State Pavlo Tychyna Pedagogical University were identified, which include: increasing the state's attention to the functioning of scientific and pedagogical schools at higher education institutions; the change of the status of Uman State Pavlo Tychyna Pedagogical University from the institute to

the university; the need for scientific research at the university, which led to the training of highly skilled pedagogical staff with academic degrees and titles; 2) the development of scientific and pedagogical schools in the university is divided into two stages: the first stage (1993-2000) - the first scientific and pedagogical schools founding; II stage (2001-2018) - the development of scientific and pedagogical schools.

Key words: scientific and pedagogical schools, university, directions of scientific schools activities. 